\title{
Disciplinary Power and the Role of the Subject at a Nineteenth-Century Danish Asylum ${ }^{1}$
}

\author{
BJøRN HAMRE
}

This article considers the ways in which psychiatric practice and power (and the role of the individual therein) were constituted in a Danish asylum, Saint Hans Hospital, at the beginning of the nineteenth century. Scholars usually turn to Foucault's History of Madness when analyzing the history of psychiatry from a Foucauldian perspective. ${ }^{2}$ By contrast, this essay works essentially from other works of Foucault, such as Psychiatric Power, Discipline and Punish, The History of Sexuality, Volume 1 (The Will to Knowledge) and "The Subject and Power." My point of departure will be the remarkable complaint lodged by a former patient of Saint Hans.

The narrative takes place in the summer of 1829. A thirty-one-year-old law student and former patient of St. Hans Hospital, Wilhelm Frydendahl (1798-1834), lodges a juridical complaint about the hospital's therapeutic methods. Frydendahl had been interned between 23 October 1828 and 1 May 1829. For eleven years prior to being committed, he was plagued with psychological troubles and, in his own words, had consulted virtually every doctor in Copenhagen. In so doing, he had become acquainted with their battery of cures, from cold showers to electro-shock therapy. Before his internment, in September 1828, he wrote to the chief surgeon at St. Hans Hospital, Johannes Henrik Seidelin. Enlightened humanist that he was, Frydendahl considered the Hospital as one of the foremost examples of the humanitarian 
treatment of psychiatric patients. His ultimate complaint to the Chancellery was thus lodged on 26 July 1829, three months after Frydendahl's release. ${ }^{3}$

\section{The Problem and the Approach}

I will argue that Frydendahl's critique provides us with an example of the way that disciplinary power works in the case of an informal indictment of the methods and practice at an asylum. I will proceed in three stages: 1) I analyze Frydendahl's critique - and the case history from which it proceeds - applying some of Foucault's primary concepts: disciplinary power, confession, pastoral power, and subjectivation; 2) I analyze Frydendahl's role as a subject in the transition from one psychiatric discourse to another; 3) I attempt to determine whether his complaint itself constitutes a bona fide critique of disciplinary power as such, or if the critique is not itself a part of the self-legitimation of disciplinary power. My approach will thus consist in unfolding the historical narratives presented in documents and exploring how certain points correspond to Foucault's conception of power and subjectivation.

Starting from a brief sketch of Wilhelm Frydendahl's polemic against the therapeutic practices at St. Hans Hospital, I argue that the claims of the investigatory commission, the Chancellery, and ultimately the Danish governmental agencies concerned, clearly show what amounted to the predominant interpretation of mental illness in 1829 . The subsequent section presents what may be called a Foucauldian analytic, as it is applied in this article. Finally, I use the historical documents to present key issues in Frydendahl's critique, as found in some of the minor points; i.e., "Punishment and Civil Re-Education," "Absence of Classification and Critical Methods," "The Guards Convey the Image of a Penal Institution," "The Importance of Patient Control." My closing section, "A Rather Moving Confession," examines the special confessional 
relationship that unfolded between Frydendahl and Seidelin. In the "Analysis," I evaluate the discussions presented earlier and close with some remarks about the role of the subject in relation to disciplinary power.

\section{The Narrative and Its Context}

The gravamen of the 1829 complaint was that diagnosis and treatment, to a large extent, approached madness as a form of moral decay. Consequently, the "cure" consisted of a moral treatment, which included (among other things) whipping, beating, and psychological punishment. The person responsible for the treatment was the hospital's chief surgeon, Seidelin, who, for example, proposed and then won a game of chess against a patient simply to show the latter how inflated his self-image was and humiliate him. Seidelin kept a tight rein on everyone at the Hospital. Frydendahl even claimed that Seidelin had built up a spy network to control both patients and staff. The complaint landed on the desk of the Chancellery and, in order to determine whether it held water, the Chancellery requested reports from staff doctors and the Hospital pastor. Doctors Hans K. Marcher and Carl A. Gjellerup, along with Pastor Struch, largely confirmed Frydendahl's account. Dr. Marcher even expanded the charges, claiming that a number of patients had died as a result of Seidelin's treatments. A sixth actor in this process was Ulrichsen, who was quartermaster at the Hospital and the one responsible for enacting certain of Chief Surgeon Seidelin's moral treatments into practice.

On the basis of Frydendahl's complaint, a commission was appointed in 1830 to investigate matters. It discovered that whipping and other corporal punishments had frequently been employed as therapeutics, and responsibility was laid at Seidelin's door. The Hospital's board of directors was issued a reprimand for failing to supervise properly conditions at the 
Hospital. By Royal decree, Seidelin was fired in 1831, and the restructuring of overall Hospital conditions was begun. The new Chief Surgeon, A. Göricke, was a somaticist and the Frydendahl case came to be inscribed in the German debate between Mentalists and Somaticists, which raged between 1805 and 1845 (Klitgaard 36).

A word is necessary, here, concerning this debate. We do not use these terms today, however in the first decades of the nineteenth century, the field of German psychiatry was divided between Somaticists and Mentalists. The foremost representatives of the Mentalists were professors of medicine (notably, J. C. A. Heinroth [1773-1843] and J. C. Reil [1759-1813]). Within German psychiatry this school of thought was speculative and profoundly inspired by Naturphilosophie, notably in its conviction that there was a connection between madness and “sin.” Indeed, in Seidelin's defence papers, there are many references to Heinroth, who assumed that spiritual disturbances were caused specifically by sins against religion. Mental illness could thus be thought of as a form of functional damage to the soul, which arose when people gave free rein to their passions. Therefore, mental illness was essentially self-inflicted. In 1803, Reil had laid the foundations for the use of the "psychic methods" of cure in his work, Rhapsodien über die Anwendung der psychischen Kurmethode und Geisteszerüttung (Rhapsodies on the Utilization of the Psychic Cure-Method and Mental Breakdowns). Along with Heinroth's ideas, Reil's comparable methods were disseminated throughout Europe and applied in numerous nineteenth century mental institutions.

The Somaticists, for their part, assumed that mental illness did not constitute a separate category of disease, but was the expression of physiological ailments that might have their source in any part of the body. By the middle of the century, the Somaticists had gained ground on the Mentalists, assisted in this by Auguste Comte's positivism, which turned on a general 
demystification of science and scientific practices (Klitgaard 48). However, at the time of Seidelin's dismissal in 1831, the Mentalists were still dominant in Danish psychiatric discourse. Therefore, the Commission defended Seidelin's actions, arguing that his methods were still recognized by notable authorities in the field. Nevertheless, the Commission did not agree that Seidelin had shown the necessary sober-mindedness and calm in the execution of his "punishments." Thus, Seidelin was dismissed less for his peculiar psychological methods than for his excessive recourse to punishment as a treatment for his patients. Indeed, on the basis of the complaints received, the Commission concluded that Seidelin no longer enjoyed the requisite public trust. On the basis of these investigations, the Chancellery wrote a recommendation to the King, intended as a guide to possible actions. Like the Commission, the Chancellery did not believe that Seidelin should be castigated for the principles legitimating his treatments. They pointed out: [t]he forcible means used could hardly be considered irredeemably reprehensible; indeed, they must sometimes be necessary and useful for curbing disorderly and destructive inclinations and to prepare the way for beneficial effects on the temperament (Sedelin 1180).

As we can see, the Commission and Chancellery did not condemn Seidelin for his choice of psychological methods, but rather for his exaggerated use of them.

\section{Foucault's Analytic in light of Practices at Saint Hans Hospital}

In this section I discuss those aspects of Foucault's analyses that inspired my examination of Frydendahl's complaint. The point of using different concepts from Foucault's oeuvre is also to determine which of the tools are the most helpful when applied to the case of Frydendahl's criticism of the conditions at St. Hans Hospital. This may allow us to view his complaint to the Chancellery from a Foucauldian perspective. 
In The History of Madness, Foucault set out to analyze the psychiatric institutionalization of madness or, as he puts it in the Preface to the first edition: the "history not of psychiatry, but of madness itself in its vivacity, before all capture by knowledge" (Foucault 1961; Lagrange 349). Given the problems and struggles that psychiatry faced in 1970s, Foucault's own focus changed in the lectures at the Collège de France (notably, in those given between 1973 and 1974), where new conceptual tools like power, knowledge, and subjection were introduced into his earlier analyses of the history of psychiatric institutionalisation. Among the new tools that I find especially illuminating for approaching the practices of psychiatric institutions is disciplinary power. According to Foucault, such a system of power

is secured by a multiplicity, a dispersion, a system of differences and hierarchies, but even more precisely by what could be called the tactical functioning of power in which different individuals occupy a definite place and ensure a number of precise functions. You have therefore a tactical functioning of power, rather, it is this tactical arrangement that enables power to exist. (Foucault, Psychiatric Power 2006)

It seems clear that the practices characteristic of St. Hans Hospital can be interpreted as instances of disciplinary power. Many of the practices there fit aptly into Foucault's descriptions of panopticism (Foucault, Discipline and Punish 195). In the case of Frydendahl, we will see that the body, his body, has been turned into a complaint through various means, including: 1) hierarchical observation; 2) normalizing judgment; and 3) examination (Foucault, Discipline and Punish 170). As we will see in the following sections of this article, practice at St. Hans thus confirms the analyses of modern institutions set forth in Discipline and Punish; notably concerning the different ways in which punishment was meted out: 1) from punitive acts performed directly on the body; to 2) the transference of the object of punishment from bodies toward souls; and finally to 3) punishment as discipline imposed through surveillance (Foucault, Discipline and Punish). 
While Discipline and Punish focuses on panopticism and its disciplinary effects, Foucault's later writings, such as The History of Sexuality and "The Subject and Power," shed light on how individuals come to govern themselves and on how the population in the modern State is constructed as an object of intervention (Foucault, Discipline and Punish; Foucault, The History of Sexuality; Foucault, "The Subject and Power") ${ }^{4}$. As we know, the ascription of a wide range of phenomena including health, illness, death, sexuality, fertility, and parenthood to the public domain of the State tended to circumscribe the latter with new discourses, knowledge, analyses, and restrictions. Of course, State intervention in the affairs of the population was similarly conducted through pastoral power. However, this particular form tended to be totalizing; viz., directed towards the national population as a whole. Thus, two modalities of power, a global and comprehensive one, and an individualizing power proved highly efficacious in normalizing a host of conditions hitherto assigned to essentially private concerns. As Foucault put it, "[f]inally, this form of [broad pastoral] power cannot be exercised without knowing the inside of people's minds, without exploring their souls, without making them reveal their innermost secrets" (Foucault, "The Subject and Power" 214). In the last section of the essay, I will attempt to determine whether "the psychological method" applied by the Chief Surgeon should be characterized as: 1) a sign of the shift from punitive acts performed directly on the body, to measures aimed at the "soul" (as mentioned above); or 2) the expression of a pastoral power able to link scientific notions of psychiatric therapy with Christian conceptions of morality and the soul, thereby constituting the specificity of the new therapeutic practices.

To be sure, confession was not an explicit part of the treatment at St. Hans, and it is never mentioned in the letters from the Hospital doctors. What is interesting is, nevertheless, the confessional character of the relationship between Frydendahl, for one, and Chief Surgeon 
Seidelin, a relationship that, I believe, would have been unthinkable in the earlier age of the Great Confinement. With confession, of course, we confront a new type of power encroaching upon the soul. A secularized confession thus becomes the path, albeit modified, to salvation in modernity.

In any case, next to testing rituals, next to the testimony of witnesses, and the learned methods of observation and demonstration, the confession became one of the West's most highly valued techniques for producing truth. We have since become a singularly confessing society. (Foucault, The Will to Knowledge 59)

The practice of confession followed a surreptitious trajectory that can be traced from the medieval sacrament of atonement to modern therapeutic practices in psychiatry, psychology, and education. Of primary interest here is whether the confessional character of Frydendahl and Seidelin's relationship represents a sign of the emergence of confessional practices in Danish psychiatry, if not in the treatment itself, then at least in the range of relationships available to patients and doctors in Danish mental institutions at the beginning of the nineteenth century.

How, then, were individuals constituted as patients at St. Hans Hospital, and what was the role of the subject in Frydendahl's case? In order to understand the processes that confronted individuals within the contemporary discourses and institutions, it is necessary first to explore how power relates to the subject. Some three years before his death, Foucault argued that it is the subject, not power per se, that had long been the primary focus of his work (Foucault, "The Subject and Power" 208). His aim would thus have been to scrutinize the various ways in which individuals are objectivated according to subject positions available within modern society. As we know, this process was characterized as subjectivation: "[being] subject to someone else through control and dependence, and tied to one's own identity by a consciousness of selfknowledge. Both [these] meanings suggest a form of power that subjugates and makes subject- 
to" (Foucault, "The Subject and Power" 212). In his late essay, "The Subject and Power," Foucault explored the ways in which individuals constructed themselves as subjects in accordance with specific discursive logics (Foucault 208). According to Foucault, the process can unfold in three different ways: first, through the objectification of the subject within discourse; second, through practices of division and sequestration in modern institutions; and third, through those practices by which human beings make themselves into subjects (Foucault, “The Subject and Power" 208). The individual is thus never simply objectivated; he/she also comes to govern him/herself according to the knowledge and categories provided by the hegemonic discourses in question. Foucault describes the genealogical approach to the subject in this way: "[o]ne has to dispense with the constituent subject, to get rid of the subject itself, that is to say, to arrive at an analysis which can account for the constitution of the subject within a historical framework" (Foucault, Power/Knowledge 117). In the section of this article entitled "Analysis," I will return to this point in light of two questions: 1) how, through power procedures, the practices at St. Hans Hospital constituted patients as subjects; and 2) how, in light of the Frydendahl case, one characterizes the role of the subject in nineteenth-century Danish psychiatry. On the basis of Foucault's concepts, I now proceed to an examination of what could be called the "archive," as it concerns one unusually visible patient.

\section{Punishment and Civil Re-Education}

Patients' complaints were hardly a new phenomenon at St. Hans. Already in 1816, shortly after Seidelin was hired as Chief Surgeon, complaints began coming in about his methods of treatment. One father complained that, upon discharge, his son had bruises and sores on his 
body. But this simply provided Seidelin with an opportunity to defend his psychological methods:

[In] all of them I have considered it my duty to tame evil by diverse means in keeping with its diverse nature, so far as I am able. I and a number of others have been successful in the short time that I have been physician to the demented in this Hospital. About the latter, in whom bad upbringing above all has gradually unfolded as an evil that often degenerates into rage, I believe, in the main, that the corporal punishment that the parents neglected at the time would prove the most powerful means for making them at least tolerable among their unhappy compatriots, and secure them from perfidious attacks. I have used this means on some five to six demented patients and have not yet seen any unfortunate effects therefrom: they are infused with fear, which is the only thing that can keep them from their harmful intent. (Seidelin 1166)

Seidelin's defence continues with descriptions of how he tried, among other things, to make up for what the parents had failed to do by beating the patients with a rod. The doctor thus steps into the shoes of an authoritative father figure who is obliged to compensate for the oversights of the parents. Frydendahl's complaint echoes Seidelin's account, while unfolding a critique of the method known as the "moral treatment."

The Chief Surgeon's psychic cure is, therefore, the same for almost everyone - namely, straightjackets, rough treatment, cold showers, beatings; in a word, all manner of violence that increases to the precise degree that he believes he has perceived, in the person's connection to madness, the evil will that presumably expressed itself therein. (Frydendahl, First account 5)

The connection between madness and evil was readily confirmed by Seidelin (First account 6). According to him, psychic illnesses "depressed" morality, something he had not only experienced himself, but also believed to have scientific foundations, thanks to the work of psychiatrists such as Heinroth and J.-É. Esquirol (Seidelin, First account 13). Grounds for punishing this evil could be anything from "naughtiness" to uncleanliness, from hysterical laughter or epileptic fits to conduct that could be interpreted as sexual. The means of punishment might be whipping, blows, cold showers, etc. Common to punishable conduct was its discernable 
source in an evil will, a notion consistent with the psychic methods of therapy. This is most clearly seen in the story of a patient, named Kofoed, who had been a grocer. This case provided Frydendahl with important material in his complaint, not to mention one of the clearest examples of subjectivation strategies common to the psychological "kurmethode." Kofoed presumably suffered from hypochondria and megalomania which, according to Seidelin, was expressed in the fact that he invariably spoke of his perfection and would not tolerate contradiction (Seidelin, First account 23). Therefore, Kofoed required re-education. At first, Seidelin tried gentler methods. But within short order, he returned to his heavy-handed tactics to break the patient's delusion. On Frydendahl's account:

One day, he ordered him to play chess and, when the foolish man made a wrong move, he seized him by the locks and dealt him light blows on the side of the head with his hand, while uttering these words: "Did he see that he moved like a stupid fool?" And when he lost the game, he exclaimed, "Does he now grasp that he is a deluded cow?" Following this, he dealt him severe blows beneath the ears when the feeble-minded man contradicted him. He further assured him that he would invariably win the game, but when Kofoed would not take his paws from his ears, as Seidelin constantly shouted, he ordered the ward orderly to fetch the rod, which also occurred. This person thereupon dealt him blows to the back. Not satisfied with this, however, the Chief Surgeon, himself in a fit of ill-temper, took hold of the rod, beat the unfortunate man on the back, thighs and wherever he could reach, screaming continuously that he should shut up and stand still, until he had backed Kofoed against the wall and ordered him not to move a limb or twitch a muscle. Thereupon he took a step or two back to see whether the man was standing as he wanted, but when he saw that he was in convulsions, he rushed toward him and beat him anew. (Frydendahl, First account 13)

Compare this with Seidelin's own account of the same episode:

About the game of chess, of which he boasted a perfect understanding, I found that he hardly knew the moves of a single piece. Therefore, after he had lost the game, and I had called his attention to this fact in a way that I thought would best affect his lethargy, and he nevertheless showed himself ill-tempered towards me, I determined it a suitable moment to try to subdue these outbursts in him, which were closely connected to his disease and failing whose suppression he would never be restored. This was the true reason for meting out corporal punishment to him. (Seidelin, First account 26) 
We hardly need to point to the infantilization of Kofoed, who was treated as a disobedient child who had to learn his limitations, rather than as a patient. Restraint and humiliation were thus fair goals in the "re-education" process, standing in for the neglected labours of the patients. The ideal thus dictated that the mad adapt themselves and learn civil virtues.

Expectations of normality in patients also appeared in the way they were (or were not) occupied. One component of Frydendahl's critique of the Hospital's therapy concerned the "unlimited monotony" to which the patients were subjected. The beauty of nature and its fresh air were one of the reasons for moving to the country, so the patients could be distracted from their troubles. However, according to Marcher, the gardens were used by Hospital officials instead. Monotony was greatest in winter, when two or three of the orderlies played cards with the patients, while many others sat idle in the dark. In principle, according to Dr. Marcher, a meaningful occupation should have been part of the practice at the institution (Marcher 19-20). In his report to the Chancellery, Seidelin conceded that more meeting halls were needed, so the patients could be occupied according to vocation. The educated classes, for example, might be occupied with music and billiards. Where occupations were lacking, compulsion was necessary instead, as Seidelin also admitted in his letter to the Chancellery (Seidelin, First account 7-8). Now, the general absence of occupations for the patients confirms the impression of a psychiatric practice in which the mad were (still) viewed as a problem typical to a subaltern social rank. Practices at the Hospital thus had more the character of warehousing and civil re-education than the authentic healing of the sick. 


\section{An Absence of Classification and Critical Methods}

Confronted with the Frydendahl case, a discussion arose concerning the prerequisites for admission to the Hospital. A crucial point in the unfolding of this debate concerned the inadequate classification of patients there: "[p]ersons may come to this undoubtedly horrible residence who are suffering little or nothing wrong with their understanding" (Frydendahl, Second account 16).

What was the classification of the patients at Saint Hans? The Hospital was outfitted with a poor ward and an infirmary. There were no further divisions between mentally healthy versus unhealthy patients, which meant that they found themselves mixed together in the same wards. According to Chancellery reports, many mentally healthy patients actually resided in the Hospital. ${ }^{5}$ In addition, many patients were promised discharge but never granted it, which worsened their condition; and the absence of diagnoses and classification made psychiatric work difficult, according to Dr. Marcher. "My intent, if possible, is to make our superior aware of a better classification of the patients for their health and welfare, which is doubly necessary where the numbers are threatening to diminish our effectiveness" (Marcher 23). Marcher found it especially grievous that, among the patients, were lawbreakers called to act as orderlies to the patients. Indeed, his criticism, along with that of others, suggest conditions closer to Foucault's descriptions of the "Great Confinement" of the seventeenth century than those of a modern hospital for the mentally ill, with its diagnostic requirements and professionalization of duties. Nevertheless, Chief Surgeon Seidelin defended the presence of cured patients (outlaws), appealing to popular fears of their backsliding upon discharge. In his self-defence, he offered comparisons with German institutes for the mentally ill with a view to showing that the number of those discharged relative to those admitted was actually higher at St. Hans—viz., over half the 
population - than in German hospitals, which only 1/6 to 1/4 of patients admitted (Seidelin, First account 29). Of course, Seidelin wrote nothing about the actual criteria for discharge, but obtaining release involved at least a nominal adaptation to stated definitions of normalcy at Saint Hans. It thus proved an easy task for Dr. Marcher to demolish Seidelin's statistics, as he easily showed that discharge occurred essentially randomly.

If one were to draw a conclusion from Mr. Frydendahl's memoir and my statements, we might say the following: if one is so stingy with patients, that is, so wary of their discharge, then society is that much the safer from exposure to the uncured-but I must immediately correct such presumptions as they could otherwise be used later on to reprove me; viz., that an important objection had eluded my attention. Grocer Skanke was declared cured by us on one particular day, only to be declared mad the following day by the whole of Copenhagen. (Marcher 25)

Among other things, Marcher demanded that a critical method be developed for the evaluation of patients. For example, the treating physician should not be the one who later determined their conditions of discharge, as he should not be called upon to assess his own work. The fact that many discharged patients quickly returned to the Hospital can be diversely interpreted, as patients acted in relation to perceived expectations for "the cured." Following discharge, the same patients encountered social or familial expectations of normality and reconstructed themselves as mad, thereby earning for themselves and the Hospital the laughter of the entire population of Copenhagen.

\section{The Guards Convey the Image of a Penal Institution}

According to the Hospital sources, the personnel was variously designated as attending personnel, outdoor servants, nurses' orderlies, orderlies, and even officers. In particular, the "officers" strengthened the image of the Hospital as a penal institution, as sketched by Frydendahl. As Quartermaster, Ulrichsen was formally the head of the attending personnel. 
These consisted of seven male orderlies, five nurses' orderlies, and eight ward maids assisting the nurses' orderlies. This personnel had a total of 160 patients in their charge (Marcher 4-6). The ward maids, recruited amongst the most capable of the patients, were to assist with cleaning. On Dr. Marcher's account, the remaining twelve orderlies and nurses' orderlies were altogether insufficient in relation to the 160 patients. This meant that patients, regardless of condition or education, were treated by the personnel according to one and the same category. Some of the consequences of this lack of personnel were that:

Our patients could escape and be gone for several hours without being missed. At night, our solid doors could be kicked to pieces without anyone thinking of answering. Our patients could be found with ruptured sores without anyone knowing where such violence came from or for how long the effect had existed. Our patients could [further] be found lying alone under trees in the rain and suffering from pains which, according to their own account, were the result of the heavy blows dealt them on the whims of the orderlies. (Marcher 7-8)

This unsettling image supports the impression of a hospital for the mentally ill whose principal function was incarceration. In practice, the institution thus fulfilled its primary goals of isolating and disciplining the mad. The personnel constituted a self-renewing population, given their place of recruitment. Dr. Marcher and others also pointed to the fact that most of the personnel were drawn from an educated farmer class, while the nurses' orderlies were taken from the poor ward.

As Senior Attendant, Quartermaster Ulrichsen was often the one charged with examining newly arrived patients and executing the initial "rod cure" (whipping with a rod). Ulrichsen himself criticized this and other practices; notably, medicines being administered by a former patient who was also responsible for cleaning and the distribution of food:

According to the Chief Surgeon's dictates, this girl attaches blood leeches to men as well as to women, and this occurs often in the most secret place of both sexes, while she also administers enemas when ordered to do so. Sometimes, patients die and their bodies are 
then autopsied. For this, the aforementioned E. R. Fals is also summoned. I have seen her frequently coming directly from such dirty business with only the time to wipe her hands on an already filthy rag, and she has immediately proceeded to distribute medicines or may begin to distribute food or tea to her patients (for she is now also used as a nurses' orderly). For this reason, she often complains to me that she must at one moment seize on the most gruesome thing imaginable - and in the next moment prepare medicines that are no less subtle than giving enemas. (Ulrichsen 2)

On Seidelin's account, mechanical processes such as bathing and the distribution of medicine could really be carried out by former patients. That the aforementioned were dismissed as routine tasks, points similarly to the striking lack of professionalization on his part and in the official discourse of the Hospital.

\section{The Importance of Patient Control}

In Frydendahl's complaint, criticism concerning patient control was important. It mentioned clearly the limitations imposed on the patients' freedom of movement, the spy network Seidelin set up, the surveillance of correspondence, and the manipulative control over patients' dismissal from the hospital.

He [Seidelin] thus assumes as something decided that every patient should feel to the highest degree that, in this place, he possesses the least ability to act freely. This principle has some truth to it, though only in part and, with respect to the causes of madness, it is probably quite mistaken so far as the patients' culpability is concerned, while the violence that results from it is excused by its necessity. Finally, its use under Chief Surgeon Seidelin makes Bidstrup-Gaard the equivalent of a cruel penal institution and not a hospital; its harmful effects on many types of madness is certainly without the slightest doubt. (Frydendahl, First account 2)

According to Frydendahl, the patients had lost all rights and were treated as prisoners. The ward guards cursed and spoke condescendingly to the sick, and blows were part of the order of the day. Order and security were considered by Seidelin to be required as long as there were no milder forms of treatment available. Control was justified as a necessary precondition for 
treatment. One of the forms of control was the "inquisitorial mien," which Seidelin saw as necessary to maintaining the patients' respect (Seidelin, First account 17-18). Moreover, letters out of the Hospital were invariably read by Seidelin; while letters from families never reached the sick, and visitors could not come to see them without the presence of the Chief Surgeon or the Quartermaster. Seidelin justified his control of the patients' correspondence by referring to an order from the Board of Directors, though he himself always found it worthwhile:

On the one hand, I often learn about their madness therefrom; on the other, as so many incorrect depictions and false conceptions about the Hospital would otherwise flow out of here that neither the family of the diseased nor the Hospital could get any use from it; and, finally, it would be inappropriate to give the insane permission, when they should be in treatment and under observation, to broadcast to friends and family all the gibberish they might have a mind to put on paper. (Seidelin, First account 32)

According to the complaint, Seidelin had built up a network in which both personnel and patients were ordered to spy on each other. On the basis of these reports, according to Frydendahl, Seidelin gave orders about how individual patients should be treated. Frydendahl himself was assigned the task of investigating whether the other doctors disparaged Seidelin behind his back.

Thus he not only uses his subordinates but even the patients to spy on each othernamely, to determine what is said and done at the Hospital in his absence. He also acts on these confused reports. My role was to provide him information about what the other doctors said and did. (Frydendahl, First account 7)

The existence of such an extensive system of espionage was flatly denied by Seidelin, though he admitted that he used the ward personnel to gain information about the condition of patients, even as he personally conducted daily inspections to keep abreast of the patients' situations. Indeed, Seidelin informed his subordinate Doctor Gjellerup that he had forbidden Pastor Struch all access to the patients after the latter criticized his methods of treatment (Struch 8, Gjellerup 3). 


\section{A Rather Moving Confession}

As I indicated at the outset, Frydendahl's admission to Saint Hans began following an exchange of letters between himself and Chief Surgeon Seidelin. Up to that point, Frydendahl had been in treatment with the Copenhagen physician, C. Otto. Otto diagnosed Frydendahl as suffering from "mental illness," consisting of protracted melancholy combined with a nervous disorder. With respect to his rational faculties, however, Frydendahl was perfectly healthy, and this was also true for his general constitution, which Otto characterized as strong (Otto 1). Nevertheless, Dr. Otto's treatment did not have the desired effect, as Frydendahl soon found himself obliged to seek help from the country's then greatest authority in the field, Chief Surgeon Seidelin from Saint Hans. The pathos and suffering are clear from Frydendahl's initial letter to Dr. Seidelin:

What I know with certainty is that I address or, rather, that I turn to you as a child toward his mother's arms, seeking to find comfort from his terror and imagined dangers. For eleven years, I have been plagued by an evil demon that persecutes me, as bad conscience persecutes the good. Therefore, with all the fear of God that a Christian can muster, I say that if you, good Doctor, cannot liberate me from this Fury that persecutes me, now that I have consulted every physician in the city, been subjected to cold showers, been electrified, etc., then I can think only of my annihilation [as a way out].

The feelings and pains about which I complain here consist of disquiet, dissatisfaction and, above all, an anxiety for which the wildest imaginings of a Shakespeare or a Hoffmann could not find words (I am forced to use such strong terms, as I do not believe I can sufficiently describe my sufferings otherwise). It is inexplicable to me how such an insane sensation can be united with what my doctors at least admit is a perfectly clear view of myself; in which, in other words, I act like a madman yet can think like a sensible one. To measure and explain all the ideas, first the one, then the other, to which the disease affixes itself, would only tire them out. I should only add that the feelings of terror and disquiet from which I suffer have no real object. (Frydendahl, Letter to Seidelin, 21 September 1828 1)

This rather moving confession was necessary if Frydendahl was to have any hope of

being considered for psychiatric treatment and to come under the contemporary psychiatric discursive regime. He clearly had to legitimize his illness by laying bare his inner self, by 
demonstrating that he had always been a God-fearing Christian, and by documenting his ability to see his illness distinctly. Through his well-written letter, with its references to the world of drama, he was able to gain the doctor's intellectual respect. Frydendahl was admitted shortly thereafter, and his initial correspondence gave rise to a protracted intimacy with the Surgeon General. Seidelin thus exempted him from the work therapy to which the other patients were obliged, and he initiated him into the Hospital's internal conflicts and into the background assumptions of his own treatment. Later, their close relationship was explained by the fact that Frydendahl had developed a special sense about how to be with Dr. Seidelin:

The cause of the good treatment I enjoyed arose solely from my own cautious behaviour in associating with Chief Surgeon Seidelin, thanks to which I felt the effects of his goodnatured side. Since Seidelin himself is dual, my conduct toward him also had to be dual; that he quite simply saw himself as such is attested by the fact that he called himself Vulcan, who was calm on the outside but burned on the inside. (Frydendahl, Second account 2)

Frydendahl was discharged in May 1829 under hazy circumstances. He was at home visiting his father in the Østerbro district of Copenhagen and, among other things, on the basis of his father's evaluation of him, Frydendahl wrote to Seidelin, confiding: "he (the father) divides me into two persons-namely, a son com il faut [sic] and an other who has been killed by you and lies buried in Bistrupgaard, for which he thanks you endlessly." (Frydendahl, Letter to Seidelin, 2 May 1829 3). Wilhelm Frydendahl's father, Jørgen Peter Frydendahl (1766-1836), was an actor at The Danish Royal Theatre and, as such, a man of high standing in Copenhagen at the time. Jørgen Frydendahl was likewise a strong paternal authority for his son.

In the health certificate he drew up, Seidelin declared Frydendahl to be perfectly well. The official diagnosis was hypochondria, which arose from a particular affection of the nervous system. Neither his rational nor his spiritual faculties had ever had anything wrong with them. 
Frydendahl had thespian blood in his veins and perhaps thanks to this, he had been fortunate enough to trick Seidelin into believing that he was healthy. He later thanked Seidelin in heartfelt tones and this may be due to the fact that he had no personal animosity toward the Chief Surgeon or, as he himself explained, to a fit of joy at being set free from what he in later letters called "that horrible residence" (Frydendahl, Second account 6). We should note that this was the same residence that Frydendahl, a few months earlier, had believed to be a stronghold of humanity.

\section{Analysis}

In 1830, Saint Hans Hospital was still in transition from the age Foucault called "The Great Confinement," which maintained correction as its primary focus, towards "The age of the Asylum" accompanied by the gradual creation of a specific science of "psychiatry." By presenting an overview of the claims found in the Frydendahl complaint, I have sketched the practices at Saint Hans at that crucial moment in the nineteenth century when neither Mentalism nor Somaticism held absolute sway.

We have seen the characteristics of the Hospital's functioning, from simple internment (criminals among the patients) to the absence of diagnostic classification of the patients, to the frequent use of corporal punishment and the recruitment of guards from the patients' ranks. I have also discussed insufficiencies in the procedure of discharge. I have argued that we find, here, the distinct presence of disciplinary power, with requisite institutional characteristics and means: 1) hierarchical observation, with the Chief Surgeon at the top of the hierarchy, aided by his organization of an internal "spy system" - such a system aptly illustrating the "disciplinary power" typical to early nineteenth-century psychiatry (Foucault, Psychiatric Power 40); 2) normalizing judgment, enacted through frequent recourse to punishment, efficiently set down 
limits to permissible deviancy; and 3) the examination, as shown in the grand rounds of the Chief Surgeon-not to mention a moralizing classification of patients and conditions. We are clearly confronted with a panoptical institution that nevertheless still preserves characteristics dating from the Great Confinement. At the same time, we can see the use of a nascent psychiatric discourse, most notably in those letters from Seidelin that referred to the psychiatric authorities of his time such as Esquirol and Reil (with special attention to "the psychological method" they developed). This discourse legitimated certain of his actions towards the patients. Now, what was the function of "the psychological method" of the time when we apply Foucault's concepts to it?

I would suggest two ways of interpreting the emergence of "the psychological method" in Denmark. First, "the psychic Kurmethode" [spiritual cure-method] shifted the object of punishment from the body to the soul. However, with the gradual transition to a Somaticist understanding of mental illness, punishment became harder to legitimate. Second, the Kurmethode can be viewed as a manifestation of a pastoral power able to legitimate punishment on both religious and scientific grounds. The power that typified the asylum required an additional element in order for its disciplinary logic to expand into subjectivating practices after the waning of the Mentalist era. By combining the Christian promise of salvation with scientific notions of truth - thereby legitimating the punitive measures taken toward the patients - the "psychological cure-method" provides an excellent example of the comprehensive enactment of pastoral power, with its accompanying subjectivation.

As Foucault argued already in The History of Madness, the patient is "subjected" as a late-comer" in a universe of "sanity." Frydendahl's complaint provides examples in which we see that the patients arriving at Saint Hans were constructed according to a number of normalizing judgments and binary identities: the lazy (as opposed to the industrious); the guilty 
(as opposed to the upright citizen); the child (as opposed to the parent); the immoral (as opposed to the moral); the demonic (as opposed to the Christian). These distinctions had, in "the psychological method," the legitimacy of scientific truths. The terminology in evidence clearly exemplifies the ways patients were subjected to the discursive conceptualization of nineteenthcentury normalcy. Further, as we know, the categorization of individuals in the psychiatric discourse flowed into the classification of perversities in the scientia sexualis (Foucault, The Will to Knowledge).

Practices at Saint Hans Hospital led to particular ways of problematizing the patient—not to mention the patient's relationship to the asylum itself. The Frydendahl-Seidelin relationship was constructed according to a confessional mode, along with child-parent relations and this, consistent with the discourse's other dichotomies: bad-good, demonic-Christian, mad-rational, etc. Frydendahl readily consented to make his recognition of his own condition available to Dr. Seidelin, so that Seidelin could in turn establish a relationship to Frydendahl's self-relation. As we have seen, confession was not an explicit part of the treatment at Saint Hans Hospital, but in the case of Frydendahl and Seidelin, psychiatry mediates a relationship between patient and doctor, which secures access for the latter to the patient's spiritual life.

As for Frydendahl - his division of himself into sensible versus mad components is an example of how modern self-reflection was on the verge of becoming the indispensable criterion for being taken seriously by the emergent psychiatric discourse. Frydendahl's strategic playacting for Seidelin, performed in confidence, may be interpreted as part of his resistance to the doctor and his methods. And where there is power there will be resistance, as Foucault famously observed (Foucault, The Will to Knowledge 95). But was this resistance directed to the psychological methods or did it intend the psychiatric discourse itself? I will discuss that below. 
As an erstwhile law student, Frydendahl knew that there were risks attached to complaining about a high-ranking civil servant such as Chief Surgeon Seidelin. Frydendahl's starting point was not that he had personally suffered harm but that he had been witness to events that made it his moral and legal duty to file a complaint. Indeed, his complaint is full of language coloured by tones of justice, humanity, ethics and morality - the language that was necessary if Frydendahl was to have any hope of attracting the Chancellery's attention. In his complaint, Frydendahl appears as an enlightened humanist, demonstrating how psychiatry had taken a wrong turn. He believed that his case could "be defended in the court of reason and morality" (Frydendahl, Second account 2-3). Thus, in his assessment of its importance, Frydendahl put aside his personal relationship to Seidelin: "I believe I must distinguish between a feeling of personal goodness and gratitude to Seidelin and my weighty duty toward the State and to Humanity" (Frydendahl, Second account 2-3).

Technologies of power concern the ways in which individuals are controlled through their transformation into scientific objects, and subjected to disciplinary powers, as we readily saw in the case of Frydendahl's complaint. In that sense, the latter's claim amounted to a critique of both the physician and the patient, each of them disciplinary subjects produced at Saint Hans Hospital. The complaint thus illustrates the emergence of a juridical subject-position-i.e., not a free one, but a subject nevertheless, acting upon discourses - utilizing new means by which to call the psychiatric practice at Saint Hans into question.

In Denmark, with Wilhelm Frydendahl and other early critics of the institutions of modernity, a different juridical subject was in fact emerging. This subject-caught up in the tension between freedom and power after the Age of Enlightenment_-insisted on a minimal right to criticize discursive and penal practices. The critique of both the practices and the discipline of 
the institutions might have opened onto new discursive practices at the Hospital. But was this right to criticize hospital practices simply a part of an overall disciplinary power? In other words, was Frydendahl's critique independent of the disciplinary power, or did it belong to it?

From a Foucauldian perspective, Frydendahl's observations illustrate well the new form of governance that had flowed out of the Age of Enlightenment and the institutions of modernity. Fundamental to this age are the ways in which freedom and discipline depend on one another (Foucault, "The Subject and Power"; Foucault, Discipline and Punish). A modern humanity necessitated new means of disciplining the individual, and Frydendahl's charges exemplify the ways in which freedom and power came to be inextricably linked to each other.

Frydendahl's accusation provides an excellent example of the way in which disciplinary power does not simply work in a top-down manner-since it is not just the Chief Surgeon and the other doctors exercising disciplinary power over the patients-but is also a bottom-up exercise: the patients can also discipline the doctors if the latter behave "abnormally," for instance, in those cases where Seidelin is carried away by his own punishments, unable to remain calm and getting into frenzied rages. Disciplinary power can also work laterally. Thus, we have doctors and guards at the Hospital criticizing other doctors and guards. These examples show in a vivid way that it is not just the doctors who normalize, discipline, and keep watch over the patients, it is also the other way around: the doctors themselves require normalization. The power relation is unstable, may be reversed, and proves reciprocal even though it is hierarchical. What Frydendahl's complaint provides is an illustration of what Foucault describes as the "democratic," bottom-up, reversible, unstable nature of disciplinary power. This is a form of resistance to psychiatric power, but it does not step out of the disciplinary framework of power. What Frydendahl demands is good medical treatment, which he considers to be beyond his own 
control. He calls on a higher disciplinary power (the Chancellery) to discipline Seidelin, rather than, say, rejecting psychiatry and the psychiatric institution altogether.

Frydendahl seems to have internalized the psychiatric discourse in his body and his soul, and in his intention to improve the psychiatric discourse Frydendahl—as the "enlightened humanist" that he is - turns to his own ends the subject positions available in the juridical discourse of his time and place. All in all, he ends up confirming the very disciplinary power upon which he seeks to act critically.

\section{Notes}

${ }^{1}$ An edition of this article has previously been published in Danish in the Swedish historical journal Scandic. Scandic has permitted an English edition of the article in PhaenEx.

${ }^{2}$ History of Madness is of course the most famous text when discussing Foucault and psychiatry but other important works are: Mental Illness and Psychology (1976). "Confinement, Psychiatry, Prison in Politics" (1988), "About the concept of the 'dangerous individual' in 19th-century legal psychiatry” (1978) and Introduction to Kant's Anthropology (2008).

${ }^{3}$ The Chancellery was the essential part of the Danish central administration and had the function of a cabinet. Drawing up documents for the king was one of the tasks devolving to the officials at the Chancellery.

${ }^{4}$ This means that the population was no longer, as in medieval times, observed as an incomprehensible mass or group, but rather as a population that could be shaped and moulded in accordance with the aims and needs of the nation.

5 This critique was raised by Frydendahl, Marcher, Gjellerup and Struch. Frydendahl even suggested that some patients were held for political reasons. 


\section{Works Cited}

Foucault, Michel. "About the concept of the 'dangerous individual' in 19th-century legal psychiatry.” International Journal of Law and Psychiatry 1, no. 1 (1978): 1-18.

-. "Confinement, Psychiatry, Prison in Politics." Philosophy, Culture: Interviews and other writings 1977-1984. Ed. Lawrence D. Kritzman. New York: Routledge, 1988. 200-205.

—. Discipline and Punish: The Birth of the Prison. London: Penguin, 1977.

—. History of Madness. London: Routledge, 2006.

-. Introduction to Kant's Anthropology. Ed. Roberto Nigro. Cambridge, MA: The MIT Press, 2008.

—. Mental Illness and Psychology. New York: Harper and Row, 1976.

-. Power/Knowledge: Selected Interviews and Other Writings 1972-1977. Ed. Colin Gordon. Cornwall, UK: The Harvester Press, 1980.

-. Psychiatric Power: Lectures at the College de France, 1973-1974. New York: Palgrave Macmillan, 2006.

—. "The Subject and Power." Beyond Structuralism and Hermeneutics. Ed. Hubert Dreyfus and Paul Rabinow. Chicago: University of Chicago, 1982. 208-226.

—. The Will to Knowledge: The History of Sexuality, 1. New York: Pantheon Books, 1978.

Klitgaard, Vibeke. Tysk psykiatri i det 19.århundrede. Copenhagen: Institut for kultursociologi, 1988.

Sedelin, Mogens. Den seidelinske slagtsbog, bind 3. Odense: 1970.

\section{Unpublished source material from St. Hans Hospital, Copenhagen City Archives:}

Chief Surgeon Johannes Henrik Seidelin. First account to the Chancellery, 18 September 1829.

Chief Surgeon Johannes Henrik Seidelin. Second account to the Chancellery, 30 April 1830.

Doctor Carl A. Gjellerup. Account to the Chancellery, 1 September 1829.

Doctor Hans K. Marcher. Account to the Chancellery, 9 September 1829. 
Letter from Frydendahl to Seidelin, 2 May 1829.

Letter from Frydendahl to Seidelin, 21 September 1828.

Medical diagnosis from C. Otto, 14 May 1829.

Pastor Struch's account to the Chancellery, 28 August 1829.

Quartermaster Ulrichsen. Description of the conditions at St. Hans Hospital, 12 September 1829.

Wilhelm Frydendahl. First account to the Chancellery, 26 July 1829.

Wilhelm Frydendahl. Second account to the Chancellery, 5 October 1829. 